\title{
Lending Methods: A Financial Performance Determinant of Deposit -Taking Microfinance Institutions in Kenya
}

\author{
Kilika S. ${ }^{1^{*}}$, Namusonge G.S ${ }^{2}$ and Sakwa M. ${ }^{3}$ \\ School of Human Resource Development \\ Jomo Kenyatta University of Agriculture and Technology \\ P.O. Box 62000-00200 \\ Nairobi \\ Kenya
}

\begin{abstract}
The purpose of the study is to describe loan lending methods as a determinant of financial performance of deposit-taking Microfinance institutions (DTMFIs) in Kenya. The study sought to determine the financial cost implications of lending methods as a key determinant of DTMFIs' financial performance. The theories included capital structure, portfolio theory, the economic theories (theory of choice, finance theory, capital investment theory, investor choice theory, preference theory and efficient capital market theory). The target population of the study was 138 DTMFIs in Kenya. The study had a total of 51 randomly sampled DTMFIs and purposively selected sample size of 102 which comprised of branch managers and finance officers working in the DTMFIs. Both qualitative and quantitative research design was employed where questionnaires were used to collect primary data, and published reports quantified the secondary data. Data analysis and interpretation were based on descriptive statistics and measures of dispersion as well as inferential statistics mainly regression analysis, Pearson correlation, factor analysis, ANOVA and Chi-square. From the study, it was evident that lending methods significantly enhanced the financial performance index by about 0.206 ( $p$ value=0.013). The study concluded that lending methods had a significant effect on the financial performance of DTMFIs in Kenya. It is recommended that unpopular lending methods by most customers, should be abolished. The institutions need to invest more in research to discover new and innovative customer-friendly lending techniques to increase the number of less labor loan portfolios in order to lower default rates, reduce costs and increase earnings. The regulator of the DTMFIs should set uniform policies for all licensed DTMFIs in regard to educating clients before their engagement with the lender. This will enable DTMFIs to be able to withstand the market competition posed competitors. The study opens up the difficulties of operating as DTMFIs to the management and regulator.
\end{abstract}

Key Words: Lending methods, Group Lending, Financial Performance, Deposit taking microfinance, PAR, ROE, ROA

\section{INTRODUCTION}

Micro finance is about providing financial services to the poor who are traditionally not served by the conventional financial institutions. Financial services accessed by the poor enables them to have control over factors of production, be more self-reliant, generate employment, enhance household income and create wealth. The three unique features that distinguish micro finance from other formal financial sector include, the smallness of loans advanced, the absence of asset based collateral and simplicity of the operation. One of the most important tools of poverty eradication should be the expansion of institutional credit facilities to large sections of the people who neither have adequate collateral nor credit history to secure or access a loan. Therefore, micro finance is about providing finance to small-scale enterprises [1].

In spite of the importance of this sector, the provision and delivery of credit and other financial services to the sector by formal financial institutions, such as commercial banks has not been enough. This means that it is extremely hard for the poor to get out of poverty due to lack of finance for their productive engagement. Therefore, new, innovative, and pro-poor modes of financing the groups that are unreached by commercial banks and other related institutions based on sound operating principles have been developed. In the recent past, microfinance institutions (MFIs) were established using either an NGO or a savings and credit co- 
operative society's framework which have been important sources of credit for a large number of low income earners and MSEs in the rural and urban areas of Kenya [2].

The licensing of MFIs to operate as deposit taking microfinance institutions (DTMFIs), has seen a rise in the number of DTMFIs in Kenya since 2009. Lending methods has taken a lead among the factors that have contributed to successful performance of DMFIs sector [3]. Microfinance through group lending, is acting as a screening device. It is playing an important role in delivering financial services to the socially and economically excluded "poor" in general. However, the change from MFIs to DTMFIs has not been without challenges. In view of the upgrading of microfinance institutions, changes in their organizational structure and structural transformation process have had effects as the anticipated transition took full course. Although a lot of information arising from published research findings on factors that have contributed to the success of DTMFIs is considerable, the degree to which lending methods have been able to determine the financial performance of the DTMFIs in Kenya has not been explored. The research will be useful in the academia world, to the MFIs, the regulatory bodies in Kenya and the general public in the country.

\section{STATEMENT OF THE PROBLEM}

Since 2009 the microfinance sector has experienced drastic transformation. Quit a number of this institutions have been licensed to operate as DTMFIs. Success has marked the transition and become an area of great interest to both policy makers and scholars. The MFIs that have since transformed have moved on to operate under the new framework. Some studies carried out globally, show that the process of transformation into formal financial institutions has faced difficulties such as the ones experienced in Uganda [4], India [5], Philippines [6] and Peru [7]. However, there are key factors that have been on play to record the successful change from MFIs to DTMFIs [8]. In Kenya MFIs performance trends have been rising, as measured against factors like loan portfolio grew from $25 \%$ in 2012 to $37.5 \%$ in 2013, active borrowers grew by $2.7 \%$ in the period between 2011 and 2013 , while the client base of the MFIs improved from 5.9\% in 2011 to $14.6 \%$ in 2013 [9]. Although a lot of information is arising from published research findings on determinants which have considerable contribution to MFIs performance from a developing country context like Kenya, lending methods have not been considered. This study was therefore set out to establish the degree to which the lending methods have been able to determine the financial performance of the DTMFIs in Kenya.

\section{LITERATURE REVIEW}

\subsection{Microfinance Institutions}

The history of micro credit is traced back to the early 1700s when an Irishman, Jonathan Swift created the Irish Loan Fund, to serve small short term loans to the poorest masses in Ireland that had been ignored by commercial banks. Mr. Swift had hopes of creating wealth in the rural areas of that country. Although Swift's idea took years to catch on, by the 1800's, the Irish Loan Fund had over 300 banks for the poor and was serving over $20 \%$ of the Irish population [10].

According to reference [10] in the 18th century similar banking systems emerged in other areas across Europe targeting the rural and urban poor when Friedrich Wilhelm Raiffeisen of Germany realized that the poor farmers were being exploited by loan sharks. He discovered that under the current lending system, the poor would never get opportunities to create wealth; they would be rotating in a cycle of borrowing and repaying without advancing in their personal economic development. To break the trend he founded the first rural credit union in 1864. This system was different from the previous banks for the owners were its members, provided reasonable lending rates and was out to sustain a sound means of community economic development [11].

The new idea of credit unions spread worldwide and by the end of the 1800 s, these micro credit systems had extended all the way from Ireland to Indonesia. Towards the end of that century similar systems were starting up in Latin America. Unlike in Europe where the credit unions were owned by its members, in Latin America ownership was with the government or private banks that were not as efficient as they were in Europe. Around the 1950's donors and government subsidies funded loans basically for agricultural workers to stimulate economic growth although the efforts were short lived. The loans eventually did not reach the poorest farmers; they ended up in the hands of the farmers who were better off and required no such services. Funds were lent out at an interest rate much below the market rate and there were not enough funds to make this viable long term. These loans were scarcely being repaid and the banks' capital was depleting quickly and when the subsidized funds ran out, there was no more money to pump into the agricultural economy as small loans or credits [11].

The emergence of innovative group lending models in the field of microfinance is celebrated as a contractual innovation that has achieved the perceptible miracle of enabling former unbankable borrowers to lift themselves through the creation of social collateral. Progressive lending plays a crucial role in sustaining the groups for their persistent delivery of microfinance services to its members. Emergency of innovative group lending models in the field of microfinance is celebrated as a contractual innovation that has achieved the perceptible miracle of enabling former unbankable borrowers to lift themselves by their own bootstraps through the creation of social collateral. This has replaced the missing physical collateral that excluded them from access to more traditional forms of financial services, like credit savings and so on [12]. Therefore, the emergency of innovative joint liability microfinance models in the field of financial intermediation has created new hopes for the poor; who are otherwise unbankable 
from the look of financial institutions. One model is the self -help group (SHGs) in India/ Grameen groups. The groups are informal in nature, owned by their members, based on solidarity, reciprocity, common interest and resource pooling. Group members are homogeneous with respect to social background; heritage or traditional occupation come together for one cause to raise and manage their collective savings for the benefit of all the peers in the particular group. Microfinance group is a social design in which people participate by making themselves socially and economically accountable to each other. A group- based lending contract effectively makes a borrower's neighbor's co - obligator to loans in the process mitigating problems created by informational asymmetries [13].

\subsection{Theoretical Framework}

The study was guided by complete review of the theoretical and empirical literature which focused on the various theories. Capital investment theory operates on the assumption that there is a constant equality between the supply of corporate funds and demand for these funds. The theory is applicable in the assumption of a constant Working capital for all periods in the future.

Investor choice theory the theory is useful to the investors for it works on the assumptions of positive marginal utility where individuals will always maximize the expected utility is wealth therefore the axioms or assumptions assist in developing rational decision making in the face of uncertainty as well as providing a set of minimum conditions for consistent and rational behavior in making investor choices.

The state preference theory is used when firms are looking for investment decisions under uncertainty within a perfect and complete capital market. State preference theory provides a conceptual basis for developing models for analyzing firm capital structure and the pricing of optimal contracts. The theory therefore is handy when thinking about finance problems both for individual investors and for the corporate managers. Finally the theory is applied in the world of uncertainty as it is useful in developing optimal portfolio decisions and optimal investment rules for firms [14].

\subsection{Conceptual Framework}

The conceptual frame work shows both the dependent and independent variables that guided the study;

\begin{tabular}{|c|c|}
\hline \multirow{4}{*}{$\begin{array}{cl}\text { Lending methods } \\
\bullet & \text { Group based } \\
& \text { methods } \\
\bullet & \text { Credit unions } \\
\bullet & \text { Village } \\
& \text { banking }\end{array}$} & \multirow{4}{*}{$\begin{array}{cl}\text { Financial performance } \\
\text { - } & \text { PAR } \\
\text { - } & \text { ROE \& ROA } \\
\text { - } & \text { Cost per client }\end{array}$} \\
\hline & \\
\hline & \\
\hline & \\
\hline Independent variable & Dependent variable \\
\hline
\end{tabular}

Figure 1: Conceptual Framework

\section{RESEARCH METHODOLOGY}

\subsection{Research Design}

The study used both qualitative and quantitative techniques. The qualitative research design is often held as the precursor to quantitative research in that it is used to generate possible leads and ideas which are used to formulate realistic and testable hypothesis which can comprehensively be tested and mathematically analyzed with standard quantitative research methods. On the other hand quantitative research design is useful for testing the results gained from qualitative research leading to a final answer and narrowing down to possible directions for follow up research to take.

\subsection{Target Population}

The target population of the study was 138 which comprised of branch managers and finance officers working in MFIs that have transformed into deposit- taking MFIs in Kenya for the period between 2009 and 2013. The period was selected to investigate the effects of financial determinants that were in play since the MFIs transformed to DTMFIs within that period of first five years of operations in the new dispensation and regulations.

\subsection{Sample and Sampling Technique}

Out of the 138 participating DTMFIs population, a 37\% population was taken for the study, giving a sample of 51 DTMFIs. According to reference [15], any sample size greater than 30 is adequate. The sample size for the study constituted 102 simply randomly selected respondents from 51 DTMFIs. The selection of these figures were based on Fwaya and his colleagues whose study population was made up of the top four executives since they were more knowledgeable in the whole performance of the 
organization [16]. The sample size of a statistical sample is the number of observations that constitute it [17]. It is typically denoted by n, a positive integer or a natural number. For the purpose of this study the following formula was used to determine the sample size as used by [18].

$$
n=\frac{N}{1+N(\alpha)^{2}}
$$

Where:

$\mathrm{n}=$ the desired sample size

$\mathrm{N}=$ the sample frame.

$\alpha=$ the margin of error $(0.05 \%)$

A sample size of 102 DTMFIs was arrived as given below;

$$
n=\frac{138}{1+138(0.05)^{2}}=102
$$

Table 1: Sample Size

\begin{tabular}{|c|c|c|c|}
\hline MFI & Target population & Sampled population & Sample size \\
\hline Faulu Kenya DTMFI & $54(39 \%)$ & 22 & 44 \\
\hline $\begin{array}{c}\text { Kenya women finance trust } \\
\text { DTMFI ltd }\end{array}$ & $48(34 \%)$ & 2 & 34 \\
\hline $\begin{array}{c}\text { SMEP deposit taking } \\
\text { microfinance ltd }\end{array}$ & $12(8 \%)$ & 3 & 6 \\
\hline Remu DTMFI Ltd & $6(4 \%)$ & 17 & 2 \\
\hline $\begin{array}{c}\text { Rafiki deposit taking } \\
\text { microfinance }\end{array}$ & $6(4 \%)$ & 1 & 2 \\
\hline $\begin{array}{c}\text { Uwezo deposit taking } \\
\text { microfinance ltd }\end{array}$ & $4(3 \%)$ & 1 & 2 \\
\hline $\begin{array}{c}\text { Century deposit taking } \\
\text { microfinance ltd }\end{array}$ & $2(1 \%)$ & 1 & 2 \\
\hline Sumac DTMFI ltd & $4(3 \%)$ & $51(37 \%)$ & 102 \\
\hline $\begin{array}{c}\text { U \& I Deposit taking } \\
\text { microfinance ltd }\end{array}$ & $138(100 \%)$ & $1 \%)$ & 2 \\
\hline Total & & 1 & 6 \\
\hline
\end{tabular}

\subsection{Data Collection}

Open-ended questionnaires were the instruments used for the study. They were categorized into two; category one made up of 51 questionnaires administered to the branch managers of the target MFIs while category two of another 51 questionnaires administered to the key informants in finance department of each MFI branch. The study used both primary and secondary methods of data collection. Primary Data was collected using 51 questionnaires given to DTMF branch managers and another 51 questionnaires given to the key informants in the finance departments. Data was collected on five variables; loan products, cost of banking services, lending interest rate, lending methods and loan repayment rates. The secondary data comprised mainly of desk review of published financial statements of the sampled DTMFIs for a period of five years (2009 - 2013) for the study. Data was collected from the Bank supervision Annual reports and Annual report on microfinance sector in Kenya for the years under review. Bank supervision Annual reports were from the Bank Supervision Department (BSD) of the Central Bank of Kenya [19]. The secondary data collected was used to cross validate the primary data collected.

\subsection{Pilot Test}

The purpose of piloting was to determine if questions were properly worded and if they would be understood by the respondents. Therefore, a trial interview was conducted among a few respondents. The respondents were selected in areas other than the randomly selected ones. A sample of 14 DTMFIs which represents a $10 \%$ of the total sample was randomly selected. The 
selected DTMFIs were not included in the final exercise of data collection in order to maintain validity and reliability of the results.

\subsection{Data Processing and Analysis}

Data collection and analysis was done with the aid of Scientific Package for Social Sciences (SPSS). Analysis was done using a combination of designs including descriptive statistics which included means, standard deviations, frequencies and percentages and inferential analysis in the form of t- test. Quantitative data was analyzed to yield descriptive and inferential statistics. Qualitative measurement was done using the likert scales and inferential statistics to test for the existence of relationships between the variables rather than the effect of one variable on another. A multiple linear regression model was used to test the significance of the influence of the independent variables on the dependent variable.

\subsubsection{Measurement of Variables Ratios}

\subsubsection{Performance Measurement}

Performance measurement is a system of monitoring the results of the activities of the organization. Monitoring system is a process and a set of tools that can help managers make decisions, inform board of directors, and report to donors, investors, and other interested parties. The following are the categories of ratios and social indicators used in performance measurement.

Table 2: Performance Ratios

\begin{tabular}{|c|c|c|}
\hline Ratio & Measurement & Formula \\
\hline $\begin{array}{l}\text { Return on equity } \\
\text { ratio (ROE) }\end{array}$ & $\begin{array}{l}\text { Measures the return on owners' investment in an } \\
\text { institution }\end{array}$ & $\mathrm{ROE}=$ Net income $\div$ average equity \\
\hline $\begin{array}{l}\text { Return on asset } \\
\text { (ROA) }\end{array}$ & $\begin{array}{l}\text { It reflects the profit margin and hence it is used to } \\
\text { measure how well the institution uses assets to } \\
\text { generate revenue. }\end{array}$ & ROA $=$ Net income $\div$ average assets \\
\hline $\begin{array}{l}\text { Operating self- } \\
\text { sufficiency } \\
\text { (OSS) }\end{array}$ & Measures how well managed the MFI is. & $\begin{array}{l}\text { Financial revenues }+ \text { other operating revenues } \div \\
\text { financial expenses }+ \text { provisions expenses }+ \\
\text { operating expenses. }\end{array}$ \\
\hline Debt/equity ratio & $\begin{array}{l}\text { Measures capital adequacy, measures the overall } \\
\text { leverage of the institution. }\end{array}$ & Total Liabilities $\div$ Total equity \\
\hline $\begin{array}{l}\text { Staff } \\
\text { productivity } \\
\text { (borrowing) }\end{array}$ & Measures efficiency in production. & $\begin{array}{l}\text { Total number of active borrowers } \\
\div \text { total number of personnel }\end{array}$ \\
\hline $\begin{array}{l}\text { Portfolio at risk } \\
\text { (PAR) }\end{array}$ & $\begin{array}{l}\text { PAR is a standard international measure of } \\
\text { portfolio quality that measures the portion of the } \\
\text { portfolio which is deemed at risk because } \\
\text { payments are overdue. PAR above } 5 \% \text { or } 10 \% \text { is a } \\
\text { sign of trouble in the MFI. }\end{array}$ & $\begin{array}{l}\mathrm{PAR}=\text { Loans due not paid on time } \\
\div \text { total loan due. }\end{array}$ \\
\hline $\begin{array}{l}\text { Operating } \\
\text { expense ratio }\end{array}$ & $\begin{array}{l}\text { Measures efficiency and productivity in terms of } \\
\text { operating expenses. The lower the ratio the higher } \\
\text { the efficiency. }\end{array}$ & $\begin{array}{l}\text { Operating expenses } \div \text { Average gross outstanding } \\
\text { portfolio }\end{array}$ \\
\hline
\end{tabular}

Source: Reference [20]

\section{RESULTS}

\subsection{Determination of Financial Cost Implications of Lending Methods as a Key Determinant of DTMFIs' Financial Performance}

The study aimed at determining the financial cost implications of lending methods as determinant of DTMFIs in Kenya. Analysis was carried out to ascertain the implications using descriptive results and the factor analysis.

\subsubsection{Descriptive of the Lending Methods as a Key Determinant of DTMFIs Financial Performance}

Table 3 indicates the data on responses on lending methods used by the studied DTMFIs on financial performance. Majority of respondents (65.8\%) prefer group based lending methods as opposed to credit unions and village banking. Only a quarter (25.7\%) of the respondents prefer credit union as their best lending method whereas majority were undecided to choose it. Lastly on village banking, $34.2 \%$ of the respondents agreed to use it with almost the same number of respondents (34.1\%) being undecided on their preference on the method. The remaining $31.7 \%$ respondents did not show preference for use of village banking as their lending 
method. A general implication of the above results is that DTMFIs prefer using group based and village banking as loan lending methods.

Table 3: Lending Methods

\begin{tabular}{llllll}
\hline $\begin{array}{l}\text { Lending } \\
\text { methods }\end{array}$ & $\begin{array}{l}\text { Strongly } \\
\text { disagree }\end{array}$ & Disagree & Indifferent & Agree & $\begin{array}{l}\text { Strongly } \\
\text { agree }\end{array}$ \\
\hline Group based & $12(14.6 \%)$ & $8(9.8 \%)$ & $8(9.8 \%)$ & $26(31.7 \%)$ & $28(34.1 \%)$ \\
Credit unions & $11(13.4 \%)$ & $14(17.1 \%)$ & $36(43.9 \%)$ & $13(15.9 \%)$ & $8(9.8 \%)$ \\
Village banking & $9(11.0 \%)$ & $17(20.7 \%)$ & $28(34.1 \%)$ & $18(22.0 \%)$ & $10(12.2 \%)$ \\
\hline$N=82($ Valid) & & & & &
\end{tabular}

\subsubsection{Determining the Financial Cost Implications of Lending Methods as a Key Determinant of DTMFIs on Financial Performance Factor Results}

From the results in Table 4, the Eigen-value corresponding to the first principle component is 1.862 which is more than the cutoff value of 1 and the total variance it explains is $62.059 \%$, thus the first factor is considered for analysis purposes.

Table 4: Total Variance

\begin{tabular}{|c|c|c|c|c|c|c|}
\hline \multirow[t]{2}{*}{ Component } & \multicolumn{3}{|c|}{ Initial Eigen values } & \multicolumn{3}{|c|}{$\begin{array}{c}\text { Extraction Sums of Squared } \\
\text { Loadings }\end{array}$} \\
\hline & Total & $\begin{array}{c}\% \text { of } \\
\text { Variance }\end{array}$ & $\underset{\%}{\text { Cumulative }}$ & Total & $\begin{array}{c}\% \text { of } \\
\text { Variance }\end{array}$ & $\underset{\%}{\text { Cumulative }}$ \\
\hline 1 & 1.862 & 62.059 & 62.059 & 1.862 & 62.059 & 62.059 \\
\hline 2 & .681 & 22.694 & 84.753 & & & \\
\hline 3 & .457 & 15.247 & 100.000 & & & \\
\hline
\end{tabular}

The component matrix in Table 5 shows the factor loadings of different lending methods as used by DTMFIs. From the results it is evident that the first principal component is comprised of the three lending methods, that is, credit unions, village banking and group based loan delivery methods with factor loadings of $84.8 \%, 76.8 \%$ and $74.4 \%$ respectively.

Table 5: Component Matrix for Lending Method

\begin{tabular}{lc}
\hline & Component \\
\cline { 2 - 2 } & 1 \\
\hline Group based & .744 \\
Credit unions & .848 \\
Village banking & .768 \\
\hline \multicolumn{2}{c}{ Extraction Method: Principal Component Analysis. } \\
& a. 1 components extracted.
\end{tabular}

\subsubsection{Multiple Regression Analysis}

Table 6 shows the regression analysis output with the Chi- square tests. This is basically the test hypothesis that there is at least some predictive capacity in regression equation giving chi square statistical significance $(0.000)$.

Table 6: Chi-Square Tests

\begin{tabular}{lccc}
\hline & Value & df & Asymp. Sig. (2-sided) \\
\hline Pearson Chi-Square & $113.412^{\mathrm{a}}$ & 68 & .000 \\
Likelihood Ratio & 102.973 & 68 & .004 \\
\hline
\end{tabular}

a. $\quad 89$ cells $(98.9 \%)$ have expected count less than 5. The minimum expected count is .05

\subsubsection{Model Summary}

The model summary table shows the proportion of variation of the dependent variables accounted for by the predictor variables. The R-squared varies from $0-1$ with 0 being the least appropriate and 1 the best variation explanation. From the model summary, the $\mathrm{R}$ squared value indicates that $25.8 \%$ of the variation in financial performance can be accounted for by independent variables (loan products, cost of banking services, lending methods, loan repayment period and loan interest rates) that are used to create the multiple regression equation an implication that the remaining $74.2 \%$ of the variation in financial performance can be accounted for by other factors not considered in this study. 
International Journal of Advances in Scientific Research and Engineering (ijasre), Vol 5 (3), March-2019

Table 7: Model Summary

\begin{tabular}{ccccc}
\hline Model & R & R Square & Adjusted R Square & $\begin{array}{c}\text { Std. Error of the } \\
\text { Estimate }\end{array}$ \\
\hline 1 & $.508^{\mathrm{a}}$ & .258 & .209 & .829 \\
\hline \multicolumn{4}{c}{$\begin{array}{c}\text { a. Predictors: (Constant), lending methods. } \\
\text { b. Dependent Variable: Financial performance }\end{array}$}
\end{tabular}

\subsubsection{Coefficients Regression Results for Determinants of Financial Performance and DTMFIs}

Since the general objective of the study was to describe lending methods as a determinant of financial performance of DTMFIs, the multiple linear regression models were used to assess the overall effect of independent variables on dependent variable.

Table 8: Multiple Regression Coefficient Estimates

\begin{tabular}{lccccc}
\hline Model & \multicolumn{2}{c}{$\begin{array}{c}\text { Unstandardized } \\
\text { Coefficients }\end{array}$} & $\begin{array}{c}\text { Standardized } \\
\text { Coefficients }\end{array}$ & t & Sig. \\
\cline { 2 - 4 } & $\mathbf{B}$ & $\begin{array}{c}\text { Std. } \\
\text { Error }\end{array}$ & Beta & & \\
\hline (Constant) & 2.480 & .611 & & 4.055 & .000 \\
Lending methods & .206 & .081 & .258 & 2.545 & .013 \\
\hline
\end{tabular}

The table above shows the standardized and unstandardized coefficient values for different independent variables, standard error and significance of the variables. In this study, the following multiple regression model was adopted (equation 1);

$P=\alpha_{0}+\alpha_{1} L+\alpha_{2} M+\alpha_{3} I+\alpha_{4} C+\alpha_{5} R+\varepsilon$

Where;

$P=$ Performance of Deposit- taking Micro finance institutions

$\alpha_{O}={ }_{\text {Intercept }}$

$L=$ Loan Products

$\mathrm{M}=$ Delivery of service Mechanism

$\mathrm{I}=$ Lending interest Rates

$\mathrm{C}=$ Costs of banking services

$\mathrm{R}=$ Repayment loans Rates

$\alpha_{1}-\alpha_{5}=$ Coefficients parameters

On supplying the coefficient estimates in Table 4.29, the equation above becomes

$P=2.480+0.009 L+0.206 M-0.132 I+0.283 C-0.059 R$

From the results, the intercept term was estimated to be 2.480 . This coefficient was statistically significant at $5 \%$ level of significance ( $\mathrm{p}$ value $=0.000$ ) and is interpreted to mean that the financial performance index is estimated to be 2.48 when all the independent variables are held constant. A unit change in lending methods results to a significant increase in financial performance index by about 0.206 ( $\mathrm{p}$ value $=0.013$ ). It is evident from the results of this study that the loan delivery mechanisms or methods have a significant influence on financial performance at DTMFIs.

\subsubsection{Correlation Results of the Variables}

Correlation analysis was used to estimate a sample correlation coefficient denoted $r$, which ranges between -1 (indicating a strong negative correlation) and +1 (indicating a strong positive correlation). Correlation coefficient quantifies the direction and strength of the linear association between the two variables. Pearson's correlation coefficient was thus used to measure the degree of relationship between the financial performance and lending methods. P-value was used to determine the significance of the variables using the criterion that a p-value less than 0.05 level of significance indicate presence of a significant relationship. Otherwise, the conclusion was that there was no statistically significant relationship between the two variables. 
International Journal of Advances in Scientific Research and Engineering (ijasre), Vol 5 (3), March-2019

Table 9: Correlation Results between Dependent and Independent Variables

\begin{tabular}{llc}
\hline & & Financial Performance \\
\hline \multirow{2}{*}{ Financial Performance } & Pearson Correlation & 1 \\
& Sig. (2-tailed) & \\
& $\mathrm{N}$ & 82 \\
& $\mathrm{~N}$ & 82 \\
Lending Methods & Pearson Correlation & $.255^{*}$ \\
& Sig. (2-tailed) & .021 \\
& $\mathrm{~N}$ & 82 \\
\hline
\end{tabular}

From the Table above, it can be concluded that, there is no significant relationship between financial performance and loan products $(\mathrm{r}=-0.066$, p-value $=0.302>0.05)$. Therefore, the null hypothesis could not be rejected.

\subsection{Hypothesis Testing}

The study used multiple regression analysis to establish the linear statistical effect of independent variables on dependent variable for this study. The null hypothesis was tested using multiple linear regression model.

\subsubsection{Test of Hypothesis}

The general multiple regression models for hypothesis was;

$$
P=\alpha_{0}+\alpha_{1} L+\alpha_{2} M+\alpha_{3} I+\alpha_{4} C+\alpha_{5} R+\varepsilon
$$

H0: there is no significant effect of lending methods on financial performance of DTMFIs. It is evident from the table that, lending methods and financial performance have a positive relationship correlation coefficient of 0.255 . This means that better lending methods causes an increase in financial performance and vice versa. Consequently p-value $(0.021)<0.05$ indicates a significant evidence to reject null hypothesis that as the decision rule was to reject $\mathrm{H} 0$ if $\mathrm{P}$ - value $\leq 0.05$ otherwise fail to reject $\mathrm{H} 0$ if $\mathrm{P}$ - value is $>0.05$. The null hypothesis is rejected.

Table 10: Summary of Hypotheses Test Results

\begin{tabular}{lcc}
\hline Hypothesis & P-values & Decision \\
\hline & & \\
H0: there is no significant effect of & 0.021 & Rejected H0 \\
lending methods on financial & & \\
performance of DTMFIs. & & \\
\hline
\end{tabular}

\section{DISCUSSION}

The general objective of the study was to describe lending methods as a determinant of financial performance of DTMFIs in Kenya with the key variable of the study being lending methods.

\subsection{Lending Methods as a Determinant Factor of Financial Performance}

The correlation analysis results indicated that there was a significant increase in the financial performance of the DTMFIs. A unit change in lending methods results to a significant increase in financial performance index by about 0.206 ( $p$ value $=0.013$ ). The findings were supported by among others key products that DTMFIs offered, group loans (85\%) and individual loans (80\%) [21]. Several research findings indicate that MFIs employ innovative lending mechanisms that are not typically used in the traditional banking sector, such as group lending [13], high frequency of repayments mechanisms [22], dynamic incentives and sequential lending [23]. All these concur with the findings of this study that lending methods have significant effect on financial performance of DTMFIs.

\subsection{Profitability and Sustainability}

In order to measure financial performance it was necessary to measure the profitability and sustainability of the DTMFIs under study. Return on assets (ROA) and Return on Equity (ROE) were the two measures of profitability and sustainability used as shown in figure 2 below. 


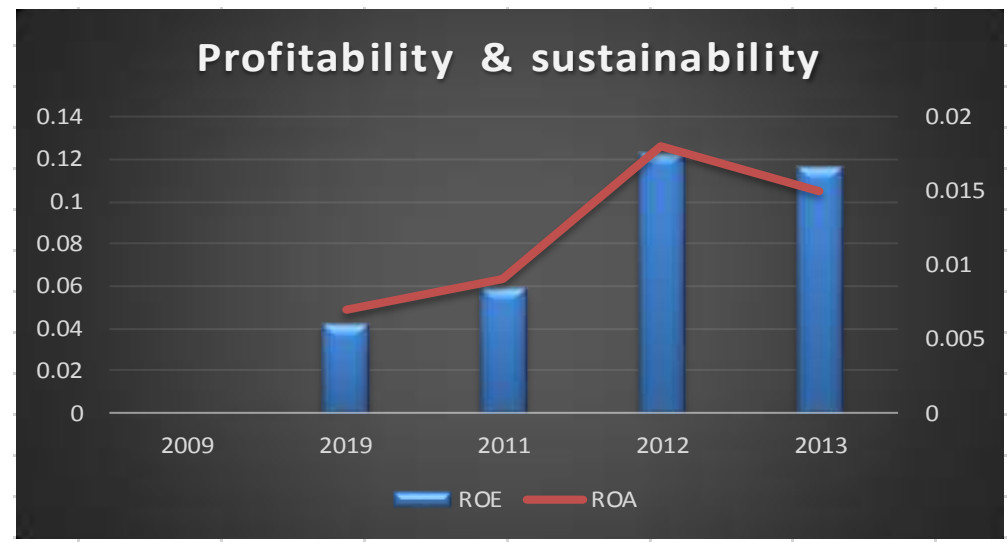

Figure 2: ROE and ROA

\subsubsection{Return on Equity (ROE)}

Return on equity (ROE) measures profitability through the return on owners' investment in the institutions. Where there is no debt, ROE ranges in the ratio of 20:1 when debt is used ROE is expected to be $40 \%$ if debt is equal to equity and $60 \%$ if debt is twice the equity. In 2010 ROE for DTMFIs was 420\%, $590 \%$ in 2011 which was $170 \%$ improvement. In 2012 ROE was $1230 \%$ which was a $760 \%$ improvement and in 2013 , ROE dropped by at least $70 \%$. Therefore, the ROE in the period under review was not steady and on average it was $850 \%$. The ROE trends showed that there were positive returns on owners" investment in the DTMFIs reviewed in the period which was a positive indication that investments done by the DTMFIs were profitable during the period under study.

\subsubsection{Return on Assets (ROA)}

In order to measure profitability, ROA was used which reflects the profit margins. ROA also measures how well the institution uses assets to generate revenue. The higher the ROA the more revenue earned. ROA increased by 20\% (from $70 \%$ to $90 \%$ ) between 2010 and 2011. The years between 2011 and 2012 experienced the greatest improvement of 50\% (90\% to 180\%) but dropped by $30 \%$ (from $180 \%$ to $150 \%$ ) in 2013 . On average the ROA was $98 \%$ in the period under review. Generally the profitability margins remained above $50 \%$ through the study period, explaining how well the institutions used their assets in generating revenue to remain profitable in the period of operating as DTMFIs.

\subsubsection{Efficiency and Productivity of the DTMFIs}

Out of the four key indicators that measure efficiency and productivity this study used Cost per Borrower Ratio. Efficiency and productivity indicators give an indication of how well an institution performs operationally. Productivity indicators reflect the amount of output per unit of input, while efficiency indicators also take into account the cost of the inputs and/or the price of outputs. Since these indicators are not easily manipulated, they are more readily comparable across institutions than profitability indicators such as ROE and Return on Assets. On the other hand, productivity and efficiency measures are less comprehensive indicators of performance than those of profitability. In an MFI the efficiency ratio may range between $10 \%, 20 \%$ or $30 \%$.

The Cost per Borrower Ratio is calculated by dividing all expenses related to the operation of the institution (including all the administrative and personnel expenses, depreciation and board fees) by the average number of active borrowers for the period. Interest and provision expenses, as well as extraordinary expenses, expenses from previous periods and other costs are not included. This ratio provides a meaningful measure of efficiency by showing the average cost of maintaining an active microcredit borrower. Since the size of the loans is not part of the denominator, institutions with larger loans do not automatically appear more efficient, as is commonly the case with the Operating Expense Ratio. The Cost per Borrower ratio is, in this sense, a "fairer" indicator than the Operating Expense Ratio.

There was a correlation between lending methodologies and efficiency. Bhandari and Kundu [5] observed that in mature markets, the average Cost per Borrower for village banks was significantly lower than the Cost per Borrower for MFIs using an individual lending methodology. This is because the clients bear the effort of selecting the individuals that form the group (as opposed to a loan officer) and also because these groups require lower operating costs. Village bank loan officers can collect repayments in one meeting, whereas officers administering individual loans must visit every borrower. The figure below shows the cost per borrower was highest in 2009 and 2010, Ksh. 150. This was immediately after the first DTMFI was licensed to operate. From 2011 to 2013 the ratio dropped drastically from Ksh. 150 to Ksh. 60 which represented a $40 \%$ rate. The improvement in the cost per borrower in the period under study indicated that the operations of the DTMFIs were working well and both efficiency and productivity were managed and controlled well. Therefore figure 3 prove that the cost per borrower was 
very high at the early years (ksh 150) when the MFIs were transforming. As they attained their full deposit-taking status, efficiency increased leading to improved productivity which was about Ksh. 57 translating to an improvement of $62 \%$.

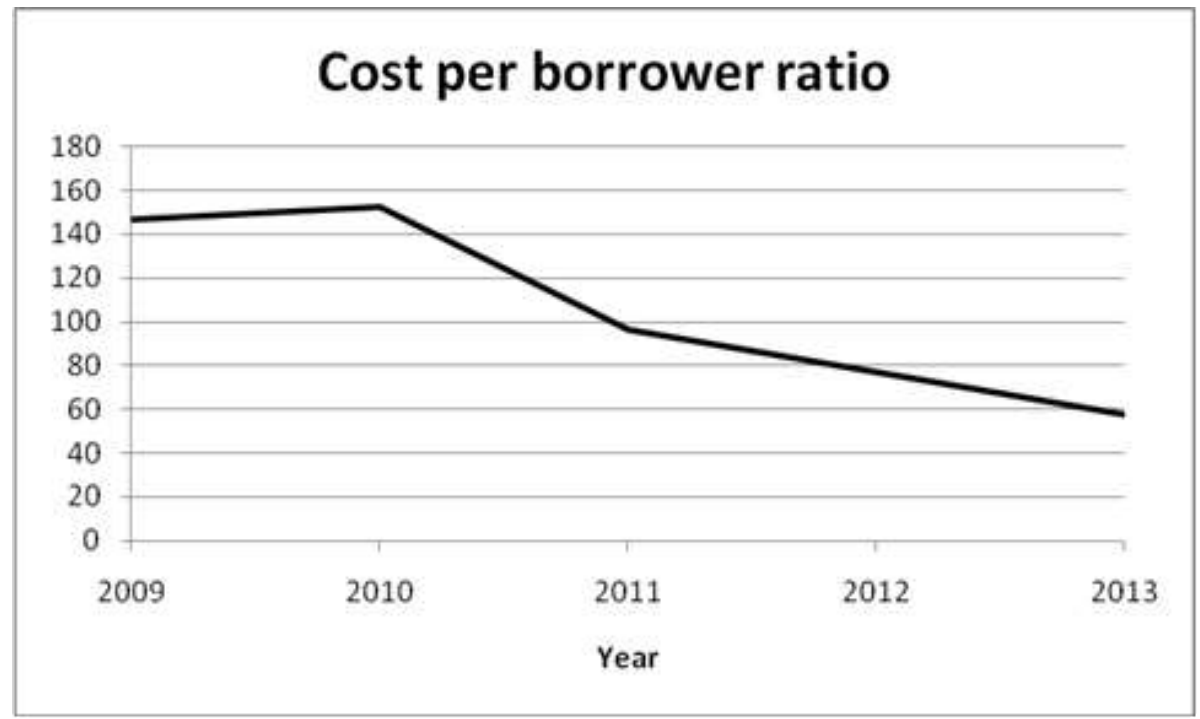

Figure 3: Cost per borrower ratio line graph for the period $2009-2013$

\subsubsection{Portfolio at Risk (PAR)}

Portfolio at Risk (PAR) is defined as the value of the outstanding principal of all loans expressed as a percentage of the total loan portfolio currently outstanding. High delinquency leads to financial sustainability being impossible for the DTMFI. PAR rates measure the outstanding balance of loans that are not being paid on time, against the outstanding balance of total loans [8]. Results in Table 6 and Figure 2 show that the highest percentages of portfolios which were at risk within the first PAR30 was between $6 \%$ and $8 \%$ followed by PAR90 which was between $3 \%$ and $5 \%$. The figure 2 indicates that PAR reduces according to the age of the portfolio. For instance, PAR 180 was between $2 \%$ and $3 \%$ while PAR365 was between $1 \%$ and $1.8 \%$, that is, PAR decreased with increase in age. The results further depicted that PAR at different ages increased in the period 2011 through 2013. PAR which is above 5\% is a sign of problem in the DTMFIs because unlike in the setting of commercial banks, microloans are not backed by bankable collateral. Therefore, DTMFIs offering loan portfolios that raged between PAR30 and PAR90 risked recovery of the portfolio more than the ones at PAR180 and PAR365.

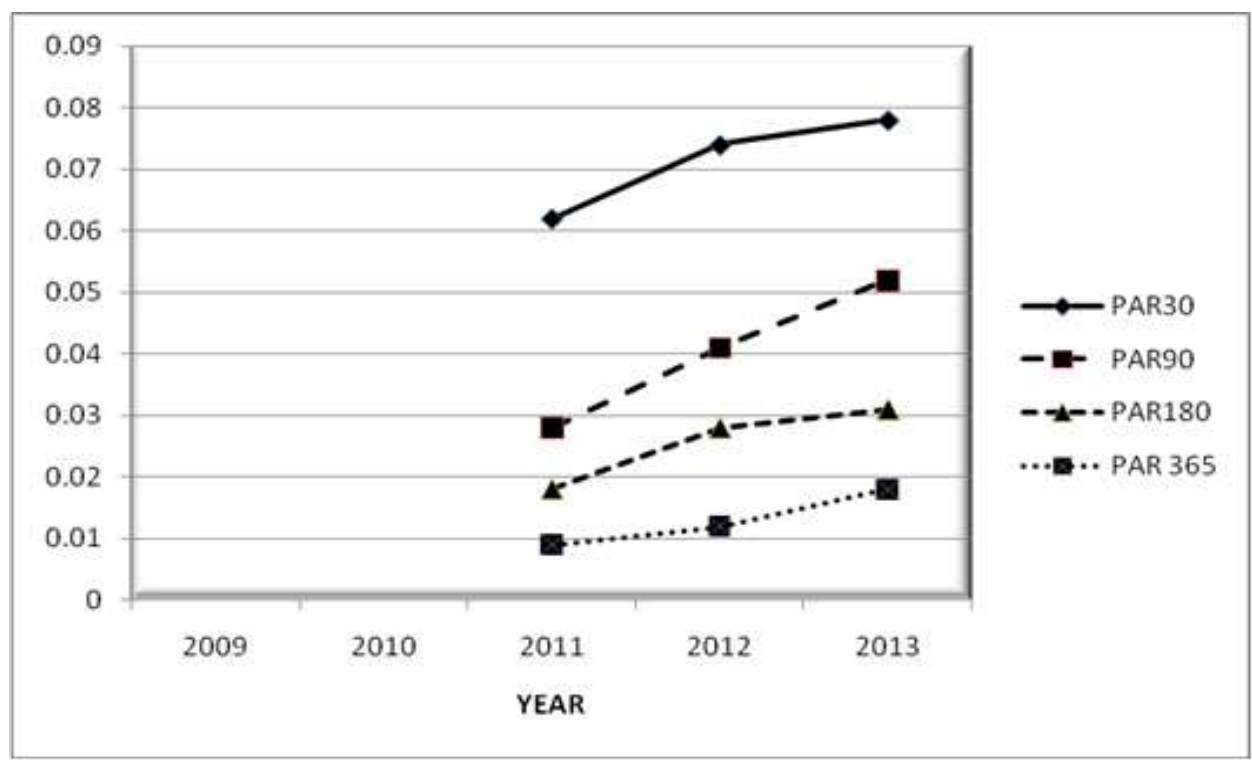

Figure 4: Portfolio at risk for the period $2009-2013$

\section{CONCLUSIONS}

The objective of the study was to determine the financial cost implications of lending methods as a key determinant of DTMFIs financial performance. This involved looking at the type of financial relationship between the lending methods and DTMFIs performance. The key indicators that were used to achieve the objective were; group based methods, credit unions and village 
banking. The descriptive statistics showed that majority of the respondents preferred group based method lending, with $65.8 \%$ of the respondents indicating that it was the most used method. Village banking was second in preference with a $34.2 \%$ preference rate by the respondents. Using the inferential statistics, the analysis indicated that lending methods had a significant effect on the financial performance of DTMFIs since there was a positive relationship between the two variables. Therefore it was true to state that most DTMFIs used group lending method to disburse their loan products more than the other lending methods.

The research findings indicated that group based lending methods were most preferred. The variable had significant effects on financial performance of DTMFIs in Kenya as indicated by the existence of a positive relationship between the two variables. Hence lending methods can be used to determine the DTMFIs' financial performance as the results have indicated.

\section{RECOMMENDATIONS}

Determinants of financial performance of DTMFIs are very critical components in our economy since they determine the financial performance of financial institutions that are intended to help the poor access loan portfolios within their capabilities. It is therefore recommended that lending methods which are not popular to most customers should be done away with. The institutions should invent other methods of lending that lead to offering more loan portfolios which are not labor intensive to reduce costs and increase earnings through innovative borrowing. The regulator of DTMFIs should set uniform policies in regard to educating clients before engagement with the lender to be used by all the licensed DTMFIs so as to cub non-compliance behaviors of loan delinquency

\section{AREAS FOR FURTHER RESEARCH}

The study used only one independent variable and one dependent variable. Other aspects of increasing the conceptual framework can be sought further to justify other determinants of financial performance of the DTMFIs. The results obtained were basically from the employees of the DTMFIs point of view, more research can be done using clients' approach to compare the responses and final results.

\section{REFERENCES}

1. R. Mersland and R.O. Strom, "Performance and Governance in Microfinance Institutions," Journal of Banking \& Finance, vol. 33, no. 4, pp.662-669, 2009

2. S. Mpira, B. Kiiza, E. Katungi, C. Staver, J.S. Tabuti, M. Kyotalimye, P. Muwumba, and M. Patten, Quantitative vs. Qualitative. Understanding Research Methods, Glendale: Pyrozack Publishing, 2004

3. C. Waterfield, "Is Transparency Enough? What is fair and Ethical in Pricing?" Lancaster, USA: MFtransparency, http://www.mftransparency.org/resources/is-transparency-enough, 2011

4. M. Sridhar, "Improving the Effectiveness of the Grameen Bank of Uganda," MSc. Thesis, Faculty of theKenan-Flagler Business School, University of North Carolina, Chapel Hill, 2015

5. A.K. Bhandari and A. Kundu, "Risk-taking Behavior in Financial Decision Making: A Village-Level Study". In Microfinance, Risk-taking Behavior and Rural Livelihood, Springer, New Delhi, pp. 15-33, 2014

6. D. Lascelles, S. Mendelson and D. Rozas, "Microfinance Banana Skins 2012. The CSFI Survey of Microfinance Risk, Centre for the Study of Financial Innovation, London, 2012

7. IFC Annual Report 2013. The power of partnerships.

8. O. Ayuma, G.S. Namusonge and M. Iravo, "Determinants of Financial Risks of Listed Companies on the Nairobi Security Ex-change in Kenya," PhD dissertation, Dept. of Accounting and Finance, Jomo Kenyatta University of Agriculture and Technology, 2015

9. AMFI, Association of Microfinance Institutions - Kenya, 2014

10. I. Matthäus-Maier and J.V. Pischke, "Microfinance Investment Funds: Leveraging Private Capital for Economic Growth and Poverty Reduction," Springer Science \& Business Media, 2006

11. FSD Kenya, The Association of Kenya Credit Providers (AKCP), 2014

12. J. Conning and J. Morduch, "Microfinance and Social Investment," Annual Review of Financial Economics, vol. 3, no. 1, pp. 407-434, 2011

13. J. Morduch, "The Role of Subsidies in Microfinance: Evidence from the Grameen Bank," Journal of Development Economics, vol. 60: 229-248, 1999

14. W.A. Barnett, "Getting it Wrong: How Faulty Monetary Statistics Undermine the Fed the Financial system, \& the Economy," Forthcoming M.I.T Press, Cambridge Mass, 2011

15. L. Bornmann, R. Mutz, S.E. Hug and H.D. Daniel, “A Multilevel Meta-Analysis of Studies Reporting Correlations between the $\mathrm{h}$ Index and 37 Different h Index Variants" Journal of Informetrics, vol. 5, no. 3, pp. 346-359, 2011

16. E.V.O. Fwaya, E. Odhuno, O. O. Kambona and O.L. Othuon, "Relationships between Drivers and Results of Performance in Kenyan Hotel Industry. Journal of Hospitality Management and Tourism," vol. 3, no. 3, pp. 46-54, 2012 
International Journal of Advances in Scientific Research and Engineering (ijasre), Vol 5 (3), March-2019

17. S. Baskarada, "Qualitative case Study Guidelines. The qualitative Report, 19 (40), 1-18, 2014

18. M. Saunders, P. Lewis and A. Thornhill, Research Methods for Business Students (5 ${ }^{\text {th }}$ ed), Harlow: Financial Times prentice-Hall, 2009

19. CBK, Central Banka of Kenya Supervision Report, Nairobi, Kenya, 2013

20. M. Zeller, C. Henry, C. Lapenu and M. Sharma, Microfinance Poverty Assessment Tool. The World Bank, 2003

21. AMFI, Association of Microfinance Institutions, Kenya, 2012

22. E. Field and R. Pande, "Repayment Frequency and Default in Microfinance: Evidence from India. Journal of the European Economic Association, vol. 6, no. 3, pp. 501-509, 2008

23. S. Ghosh and V.E. Tassel, Microfinance, Subsidies and Dynamic Incentives, Working paper: http://econpapers.repec.org/paper/falwpaper/07001.htm 